\begin{tabular}{|c|c|c|c|}
\hline \multirow{2}{*}{$\begin{array}{c}\text { LARUS } \\
\text { Hrvatska akademija } \\
\text { znanosti i umjetnosti }\end{array}$} & 54 & $\begin{array}{c}35-43 \text { str. } \\
1 \text { tablica, 2 slike }\end{array}$ & Zagreb 2019 \\
\cline { 2 - 4 } & $(2019)$ & \multicolumn{3}{|c|}{$\begin{array}{c}\text { Primljeno 11.9.2019. } \\
\text { Prihvaćeno na sjednici Razreda za prirodne znanosti HAZU 21.11.2019. }\end{array}$} \\
\hline
\end{tabular}

UDK 598.288.6(497.5)

Original scientific paper Izvorni znanstveni članak DOI: https://dx.doi.org/10.21857/y6zolb8q0m

\title{
TWO SPECIES OF ORPHEAN WARBLERS Sylvia hortensis, S. crassirostris IN CROATIA: DATA OVERVIEW AND IMPLICATIONS FOR FUTURE RESEARCH
}

\author{
Velike grmuše Sylvia hortensis, S. crassirostris u Hrvatskoj: pregled \\ podataka i implikacije za buduća istraživanja
}

\section{MILOŠ MARTINOVIĆ}

Institute of Ornithology, Croatian Academy of Sciences and Arts, Gundulićeva 24, 10000 Zagreb, CROATIA

\begin{abstract}
Orphean Warblers Sylvia hortensis and S. crassirostris are two similar species that have recently been split from a single species complex. It is considered that only S. crassirostris breeds in Croatia. The data collected on this species in Croatia, however, is inconsistent as some ornithologists still use either name. In order to discern whether both species occur in Croatia, I conducted a study of citizen science data and a review of skins in three museum collections. There was a specimen of S. hortensis in the collection of the Institute of Ornithology, collected on the island of Brač in 1964. Citizen science data yielded no verifiable observations of $S$. hortensis in Croatia. Bill length was an unreliable distinction characteristic between the two species, while plumage characteristics proved useful only for adult birds. Reliable distinction characteristics are thus song, tail and moult pattern and mt-DNA. Detailed studies of Orphean Warblers' distribution and characteristics in Croatia and Italy are recommended.
\end{abstract}

Keywords: Western Orphean Warbler, Eastern Orphean Warbler, distribution, museum collections, skin review, citizen science, Brač

e-mail: martinovic@hazu.hr 


\section{INTRODUCTION}

The Orphean Warblers are two very similar species of Sylvia warblers: The Western Orphean Warbler Sylvia hortensis and the Eastern Orphean Warbler Sylvia crassirostris. S. hortensis breed from the Iberian Peninsula and Morocco along the Mediterranean region in southern France and northern Africa to Italy and northern Algeria, while S. crassirostris breeds from southern Slovenia and coastal Croatia, across the southern Balkan Peninsula, the Middle East and Transcaucasia to Pakistan. In the Mediterranean, both prefer richly structured maquis, patches of tall bushes in agricultural land, olive groves or open woodlands with bushy undergrowth (ShiriHai et al. 2001). They winter in the Sahel belt of Africa, while many S. crassirostris also winter around the Gulfs of Persia and Oman, as well as throughout India. Two subspecies of $S$. hortensis and three subspecies of S. crassirostris are currently recognised (Del Hoyo et al. 2019).

The two were regarded as subspecies of S. [hortensis] until SHIRIHAi et al. (2001) proposed to split them into two species. The International Ornithological Congress added S. crassirostris as a separate species in 2008 (GILl et al. 2019). Critical differences include plumage, biometrics, song, mt-DNA and moult differences (Shirihai et al. 2001). Svensson (2012) further tested the plumage and biometric differences, giving detailed instructions on discerning between them according to tail pattern. All sources agree that distinguishing between the two based on song is straightforward (SHIRIHAI et al. 2001).

Historically, ornithologists in Croatia have generally adhered to official taxonomies when dealing with Orphean Warblers. Most historical data refer only to $S$. hortensis and among rare historical sources that considered subspecies, only S. h. crassirostris is listed for Croatia (Matvejev \& VAsić 1973). After the split, most ornithologists and surveys have continued using the single-species system (BARIšić et al. 2016, Mikulić et al. 2016), while others document only S. crassirostris (Lukač \& STelko 2016). This potentially leads to much confusion when reviewing the data. At any rate, all agree and accept that only the Eastern Orphean Warbler is present in Croatia, be it S. h. crassirostris or S. crassirostris (KRALJ et al. 2013, Tutiš et al. 2013). However, while conducting fieldwork on the island Brač in June 2015, I encountered an individual that unmistakably sang the Western variant of the song. That event inspired me to conduct this study.

The aim of this study was to establish whether both S. hortensis and S. crassirostris are present in Croatia, and to determine the quality of citizen science data on these species. 


\section{METHODS}

\section{Citizen science data review}

I collected available S. hortensis and S. crassirostris records in Croatia from online citizen science platforms. These offer a valuable base of bird observations, so I contacted fauna.hr (BIOM 2019), eBird (EBIRD 2019) and observation.org (DE VRIES 2019) for access to their data, as well as that of the Global Biodiversity Information Facility (GBIF 2019). The xeno-canto website was also checked because it offers a valuable source of direct inspection of sound recordings, thus verifying the species of observations. Bird images were identified according to plumage characteristics described in Svensson (2012), while sound recordings were identified according to song recordings in Birdguides LTD. (2006). Any non-verifiable data was discarded due to the likelihood of mixing the species up and consequential uncertainty of records.

\section{Skin collection review}

I visited three bird skin collections known to have specimens of either $S$. hortensis or S. crassirostris from Croatia: (1) The Croatian Academy of Sciences and Arts' Institute of Ornithology (CASA), (2) The Croatian Natural History Museum in Zagreb (CNHM), and (3) The Natural History Museum Vienna (NHMV). In order to check the species, specimens were measured for length of bill from skull and inspected for plumage parameters: colouration of undertail coverts and outer tail feathers according to Svensson (2012), depicted in Figure 1. The specimens' sex, age and collection location were also noted.

\section{RESULTS}

\section{Citizen science data review}

The review yielded very little verifiable data. Among 296 collected observations of either species, none had sufficiently detailed photographs for identification. Four observations had audio recordings, all of them of S. crassirostris.

\section{Skin collection review}

I inspected 20 specimens in the CASA collection, 9 specimens at the CNHM and 7 at the NHMV (Appendix 1). One specimen (CASA no. 5973) was identified as S. hortensis, a bird collected near Nadsela, Brač in 1964 (Figure 2). Among the rest, 27 were $S$. crassirostris and 8 were unreliable for various reasons (mostly juveniles). The average bill size of $S$. crassirostris in collections was $18.98 \mathrm{~mm}$ (17-20 $\mathrm{mm}$, SD 0.79), while the bill size of the analysed $S$. hortensis specimen was 17.5 mm (Brač). An additional specimen (CASA no. 2170), collected near Metković, 
had a tail pattern similar to those in S. hortensis. However, that specimen did not have outer tail feathers on one side of its tail, which disabled verification, and its bill size $(20 \mathrm{~mm})$ was out of range previously observed for $S$. hortensis. It was therefore classified as "uncertain".

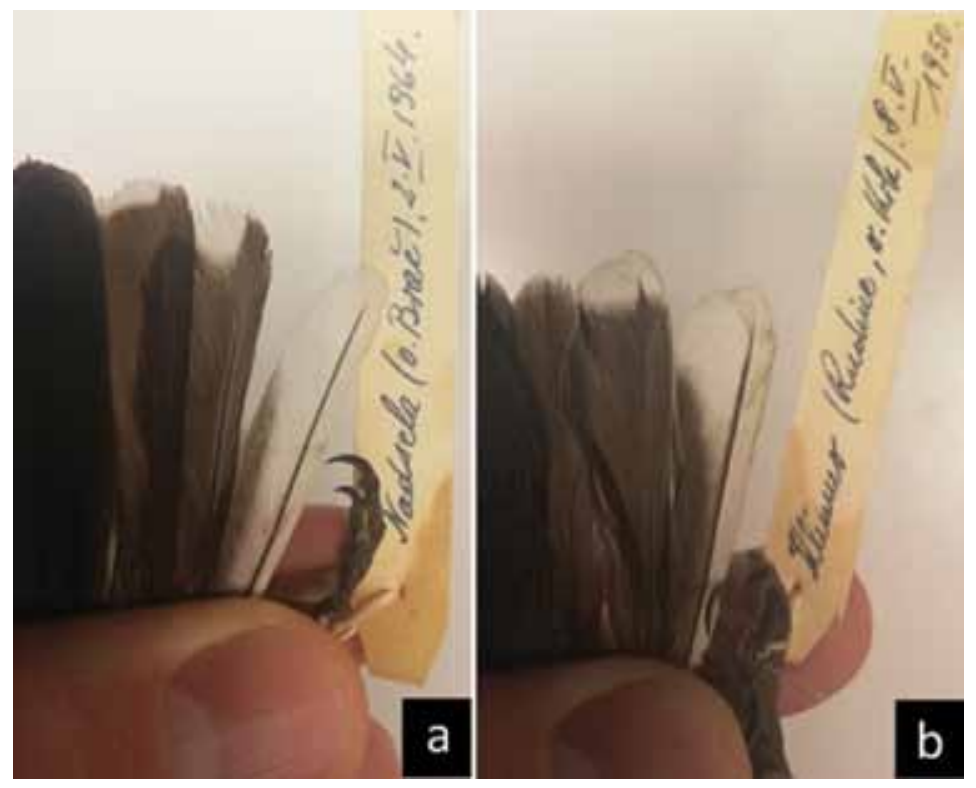

Figure 1. Tail patterns of the Western Orphean Warbler Sylvia hortensis, a) and Eastern Orphean Warbler S. crassirostris, b). S. hortensis are characterised by a long and narrow white wedge along the inner web of the outermost tail feather (a). S. crassirostris has a shorter and wider white wedge (b).

Slika 1. Uzorci na repu zapade velike grmuše Sylvia hortensis, a) i istočne velike grmuše S. crassirostris, b). S. hortensis ima dug i uzak bijeli potez duž unutarnje zastavice šestog repnog pera (a). S. crassirostris ima kraći i širi bijeli klin (b).

\section{DISCUSSION}

Considering the confirmed presence of $S$. crassirostris in Apulia, south-eastern Italy since 2010 (JANNi \& Fracasso 2012, Todisco 2013) and how this study has confirmed the presence of $S$. hortensis in Croatia, it seems that the Adriatic Sea is not a definitive geographical barrier for Orphean Warblers. One possible explanation is that some $S$. hortensis that migrate to mainland Italy via Tunisia and Sicily might "overshoot" their destinations and end up on south-Adriatic islands. Another might be that some S. hortensis wintering in central Sahel with S. crassirostris join them on their northward migration, or vice versa. The latter might explain why individuals of $S$. crassirostris are observed in south-eastern Italy. At any rate, the current quality of data on the two species in Croatia is 
insufficient for discerning any distribution patterns. It is therefore necessary to conduct a targeted study with the goal of establishing the extent of the presence of S. hortensis in Croatia.

Regarding identification characteristics, some adult specimens that seemed to be $S$. crassirostris showed tail patterns similar to $S$. hortensis. This might be an indication of a more gradual phenotypic change between Western and Eastern Orphean Warblers, as some might exhibit characteristics of both (e.g. tail pattern of $S$. hortensis and bill length and undertail coverts of $S$. crassirostris).

In conclusion, it seems that the most reliable characteristics for distinguishing between S. hortensis and S. crassirostris are song and mt-DNA (SHiRinar et al. 2001.), followed by tail pattern (Svensson 2012) and moult pattern. I recommend birdwatchers in Croatia to pay closer attention to these species, especially when on Dalmatian islands. Furthermore, a more detailed study, including song and mt-DNA analyses, is required in order to determine whether the two species of Orphean Warblers in Croatia have overlapping distributions. A study is also needed to test the reliability of plumage characteristics of both Orphean Warbler species in Croatia. These studies should include specimens from other regional collections as well, such as Ljubljana, Split, Metković, Belgrade etc. Studies with the same aims need to be conducted in southern Italy as well.

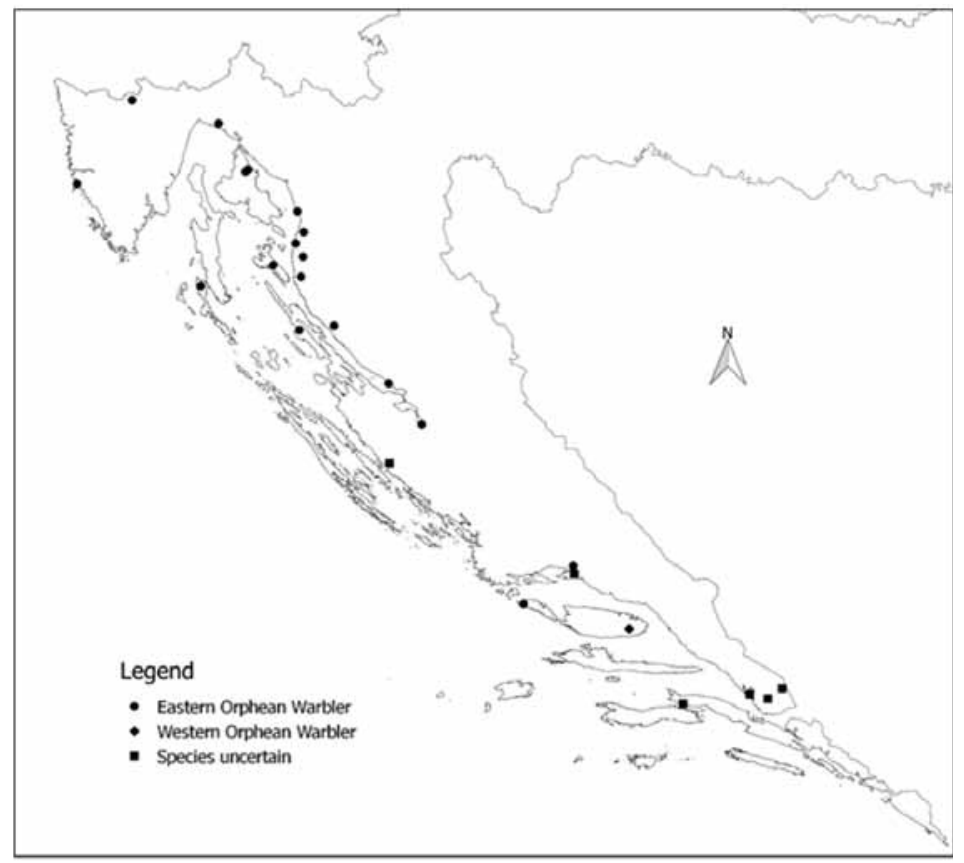

Figure 2. Locations where skins and voice recordings of analysed Orphean Warblers were collected. Sampling locations were approximated from locality names.

Slika 2. Lokacije prikupljanja preparata ili snimaka pjeva analiziranih velikih grmuša. Lokacije uzoraka procijenjene su iz naziva lokaliteta. 


\section{Acknowledgements}

I would like to thank Jelena Kralj for her constructive observations and guidance provided for this research. I am also very grateful to Hans-Martin Berg for assistance in the Viennese Natural History Museum, as well as to Irena Grbac for assistance in the Croatian Natural History Museum in Zagreb. Thanks to all the online citizen science platforms for letting me use their data: ebird.org, fauna. $h r$, gbif.org, observation.org and xeno-canto.org. Finally, great thanks to anonymous reviewers for their valuable comments.

\section{References}

Barišić, S., KRALJ, J., JuRINović, L. (2016): Rare birds in Croatia: The fourth report of the Croatian birds rarities committee. Larus 51: 38-65.

Biом (2019): Fauna.hr Dataset. Udruga Biom, Zagreb.

BiRDGUides LtD. (2006) BWPi 2.0.1. Birds of the Western Palearctic Interactive DVD ROM, Oxford University Press \& BirdGuides Ltd.

De VRIES, H. (2019): Observation.org data. Stichting Observation International, Amsterdam.

Del Hoyo, J., Collar, N., Christie, D. A., Kirwan, G.M. (2019): Eastern Orphean Warbler (Sylvia crassirostris). In: Del Hoyo, J., Elliott, A., Sargatal, J., Christie, D.A.,De JUANA, E. (eds.) Handbook of the Birds of the World Alive. Lynx Edicions, Barcelona. https://www.hbw.com/node/1343947 (accesss on 25 August 2019).

EBIRD (2019): eBird Basic Dataset. Version: EBD_relJul-2019. Cornell Lab of Ornithology, Ithaca, New York.

GBIF.org (2019): GBIF Occurrence Download. https://doi.org/10.15468/dl.qktakf (accessed on 10 September 2019).

Gill, F., D Donsker, D. (eds.) (2019): IOC World Bird List (v9.2). doi : 10.14344/IOC. ML.9.2. https://www.worldbirdnames.org/updates/archives/species-v1/ (accessed 8 November 2019).

Janni, O., Fracasso, G. (2012): Commissione Ornitologica Italiana (COI) - Report 24. Avoceta 36: 81-88.

Kralj, J., Barišić, S., Tutiš, V., Ćiković, D. (eds.) (2013): Atlas selidbe ptica Hrvatske. HAZU, Zagreb.

Lukač, G., Stelko R. (2016): Atlas ptica Istre. Natura Histrica, Pula.

Matvejev S. D., Vasić V. F. (1973): Catalogus Faunae Jugoslaviae, IV/3, Aves. SAZU, Ljubljana.

Mikulić, K., KapejJ, S., Zec, M., Katanović, I., Budinski, I., Martinović, M., Hudina, T., ŠoštaRić, I., JeČMenica, B., Lucić, V. (2016): Final report for Aves taxon. In: Mrakovčić, M., Mustafić, P., Jelić, D., Mikulić, K., Mazija, M., Maguire, I., Šašić Kljajo, M., Kotarac, M., Popijač, A., Kučinić, M., Mesić, Z. (eds.) Projekt integracije EU Natura 2000 - Field survey and laboratory processing for the collection of new inventory data for the taxonomic groups: Actinopterygii and Cephalaspidomorphi, 
Amphibia and Reptilia, Aves, Chiroptera, Decapoda, Lepidoptera, Odonata, Plecoptera, Trichoptera. OIKON-BIOM- HID-HYLA-NATURA-CKFF-GEONATURA-HRVATSKI PRIRODOSLOVNI MUZEJ-TRAGUS, Zagreb: 1-34.

Shirihai, H., Gargallo, G., Helbig, A. J. (2001): Sylvia Warblers: Identification, taxonomy and phylogeny of the genus Sylvia. Christopher Helm, London.

Svensson, L. (2012): A new subspecies of Western Orphean Warbler Sylvia hortensis and criteria for separating Western from Eastern Orphean Warbler S. crassirostris. Bulletin of the British Ornithologists' Club 132(2): 75-83.

Todisco, S. (2013): XC140544 - Eastern Orphean warbler Sylvia crassirostris recording in southern Italy. Xeno-canto Online Articles. www.xeno-canto.org/140544 (access on 8 November 2019).

Tutiš, V., Kralj, J., Radović, D., Ćiković, D., Barišić, S. (2013): Crvena knjiga ptica Hrvatske. Ministarstvo zaštite okoliša i prirode, Državni zavod za zaštitu prirode, Republika Hrvatska.

\section{SAŽETAK}

Velike grmuše Sylvia hortensis i S. crassirostris dvije su slične vrste koje su tek nedavno razdovjene iz jedinstvenog kompleksa vrsta. Razlikovanje dviju vrsta na terenu vrlo je teško ako se ne čuje pjev, a za raspoznavanje u ruci najkorisniji su obojenje perja repa i podrepka. Smatra se da se u Hrvatskoj gnijezdi samo istočna velika grmuša S. crassirostris. Međutim, dosad prikupljena opažaja ovih dviju vrsta u Hrvatskoj nedosljedna su jer neki ornitolozi koriste „stari“ znanstveni naziv S. hortensis dok drugi koriste "novi“ S. crassirostris. Prikupljena su provjerljiva opažanja ovih vrsta s portala građanske znanosti te su pregledani primjerci u trima znanstvenim zbirkama. Ustanovljena je jedna jedinka zapadne velike grmuše S. hortensis u zbirci Zavoda za ornitologiju, prikupljena 1964. g. na Braču. S portala građanske znanosti prikupljena su četiri provjeljiva opažanja istočne velike grmuše u Hrvatskoj i nijedno opažanje zapadne velike grmuše, no ustanovljeno je opažanje jedinke istočne velike grmuše u jugoistočnoj Italiji. Rezultati potvrđuju prisutnost zapadne velike grmuše u Hrvatskoj te upućuju na mogućnost da jednike obiju vrsta prijeđu na suprotnu stranu Jadrana. Pouzdane karakteristike za raspoznavanje su pjev, uzorak na repu, uzorak mitarenja te mitohondrijska DNA. Preporučena su detaljnija istraživanja rasprostranjenosti i značajki velikih grmuša u Hrvatskoj. 
Appendix 1. Data on examined museum specimens of Orphean Warblers (Sy/via hortensis, S. crassirostris). Collections: CASA - Croatian Academy of Sciences and Arts, Institute of ornithology; CNHM - Croatian Natural History Museum in Zagreb; NHMV - Nature History Museum Vienna.

Prilog 1. Podaci o pregledanim primjercima velikih grmuša (Sylvia hortensis, S. crassirostris). Zbirke: CASA - Hrvatska akademija znanosti i umjetnosti, Zavod za ornitologiju; CNHM - Hrvatski prirodoslovni muzej Zagreb; NHMV - Prirodoslovni muzej Beč.

\begin{tabular}{|c|c|c|c|c|c|c|}
\hline Collection & $\begin{array}{c}\text { Inven- } \\
\text { tory } \\
\text { number }\end{array}$ & Species & Locality & $\begin{array}{l}\text { Date of } \\
\text { collection }\end{array}$ & Notes & $\begin{array}{c}\text { Bill } \\
\text { to } \\
\text { skull } \\
(\mathrm{mm})\end{array}$ \\
\hline CASA & 271 & $\begin{array}{l}\text { Sylvia hortensis/ } \\
\text { crassirostris }\end{array}$ & Split & $14 / 07 / 1940$ & juvenile & 19.5 \\
\hline CASA & 272 & $\begin{array}{l}\text { Sylvia hortensis/ } \\
\text { crassirostris }\end{array}$ & $\begin{array}{l}\text { Viganj, } \\
\text { Pelješac }\end{array}$ & $12 / 07 / 1941$ & juvenile & 19 \\
\hline CASA & 273 & Sylvia crassirostris & $\begin{array}{l}\text { Viganj, } \\
\text { Pelješac }\end{array}$ & 14/07/1941 & & 18.5 \\
\hline CASA & 453 & Sylvia crassirostris & $\begin{array}{l}\text { Viganj, } \\
\text { Pelješac }\end{array}$ & 15/07/1941 & & 17 \\
\hline CASA & 454 & Sylvia crassirostris & $\begin{array}{l}\text { Viganj, } \\
\text { Pelješac }\end{array}$ & 15/07/1941 & & 19 \\
\hline CASA & 1683 & Sylvia crassirostris & Soline, Krk & $17 / 07 / 1947$ & & 19.5 \\
\hline CASA & 2169 & Sylvia crassirostris & Metković & $11 / 05 / 1948$ & & 20 \\
\hline CASA & 2170 & $\begin{array}{l}\text { Sylvia hortensis/ } \\
\text { crassirostris }\end{array}$ & Metković & $29 / 04 / 1948$ & $\begin{array}{l}\text { mixed } \\
\text { charac- } \\
\text { teristics }\end{array}$ & 20 \\
\hline CASA & 2933 & Sylvia crassirostris & Metković & 20/05/1949 & $\begin{array}{l}\text { no max- } \\
\text { illa }\end{array}$ & \\
\hline CASA & 3455 & Sylvia crassirostris & Klimno, Krk & 08/05/1950 & & 17 \\
\hline CASA & 3651 & $\begin{array}{l}\text { Sylvia hortensis/ } \\
\text { crassirostris }\end{array}$ & $\begin{array}{c}\text { ušće Ner- } \\
\text { etve }\end{array}$ & $22 / 07 / 1950$ & juvenile & 20 \\
\hline CASA & 4275 & Sylvia crassirostris & Rovinj & 09/06/1954 & & 19 \\
\hline CASA & 4398 & Sylvia crassirostris & $\begin{array}{c}\text { Štrped, } \\
\text { Buzet }\end{array}$ & $07 / 06 / 1955$ & & 19.5 \\
\hline CASA & 5046 & Sylvia crassirostris & Split & 07/06/1958 & & 18.5 \\
\hline CASA & 5379 & Sylvia crassirostris & Šćrbak, Rab & $02 / 06 / 1960$ & & 20 \\
\hline CASA & 5402 & Sylvia crassirostris & $\begin{array}{l}\text { Lukovo, } \\
\text { Jurjevo }\end{array}$ & 03/07/1960 & & 18.5 \\
\hline CASA & 5574 & Sylvia crassirostris & $\begin{array}{l}\text { Lopci, Jur- } \\
\text { jevo }\end{array}$ & 26/05/1961 & & 19 \\
\hline
\end{tabular}




\begin{tabular}{|c|c|c|c|c|c|c|}
\hline CASA & 5586 & Sylvia crassirostris & $\begin{array}{c}\text { Velebit, } \\
\text { Šušanj, Kar- } \\
\text { lobag }\end{array}$ & $30 / 05 / 1961$ & & 18.5 \\
\hline CASA & 5589 & Sylvia crassirostris & $\begin{array}{c}\text { Velebit, } \\
\text { Dundovića, } \\
\text { Podi, Jabla- } \\
\text { nac }\end{array}$ & $31 / 05 / 1961$ & & 20 \\
\hline CASA & 5973 & Sylvia hortensis & $\begin{array}{l}\text { Nadsela, } \\
\text { Brač }\end{array}$ & 02/05/1964 & & 17.5 \\
\hline $\mathrm{CNHM}$ & 241 & Sylvia crassirostris & Rijeka & 09/08/1888 & & 19 \\
\hline $\mathrm{CNHM}$ & 242 & Sylvia crassirostris & Split & 21/07/1899 & & 19 \\
\hline CNHM & 243 & Sylvia crassirostris & Split & 19/07/1899 & & 19 \\
\hline CNHM & 244 & Sylvia crassirostris & Spljet & 05/04 & & 19 \\
\hline CNHM & 247 & Sylvia crassirostris & Maslinica & 26/07/1899 & & 19.5 \\
\hline $\mathrm{CNHM}$ & 251 & Sylvia crassirostris & Senj & 03/05/1901 & & 19.5 \\
\hline $\mathrm{CNHM}$ & 252 & $\begin{array}{l}\text { Sylvia hortensis/ } \\
\text { crassirostris }\end{array}$ & $\begin{array}{l}\text { Sv. Filip i } \\
\text { Jakov }\end{array}$ & 13/07/1900 & juvenile & 18.5 \\
\hline $\mathrm{CNHM}$ & 254 & Sylvia crassirostris & Solin & 28/04/1900 & & 19.5 \\
\hline $\mathrm{CNHM}$ & 399 & Sylvia crassirostris & Rijeka & $13 / 04 / 1888$ & & 18.5 \\
\hline NHMV & 59754 & Sylvia crassirostris & Karin & 02/05/1901 & & 19.5 \\
\hline NHMV & 59749 & Sylvia crassirostris & Karin & $23 / 05 / 1901$ & & 20 \\
\hline NHMV & 59750 & Sylvia crassirostris & Lošinj & 04/05/1905 & & 18 \\
\hline NHMV & 12864 & $\begin{array}{l}\text { Sylvia hortensis/ } \\
\text { crassirostris }\end{array}$ & Metković & 14/07/1894 & $\begin{array}{c}\text { uncer- } \\
\text { tain }\end{array}$ & 20 \\
\hline NHMV & 12863 & $\begin{array}{l}\text { Sylvia hortensis/ } \\
\text { crassirostris }\end{array}$ & Dalmatien & 07/1894 & $\begin{array}{l}\text { uncer- } \\
\text { tain }\end{array}$ & 18.5 \\
\hline NHMV & 12865 & $\begin{array}{l}\text { Sylvia hortensis/ } \\
\text { crassirostris }\end{array}$ & Opuzen & 29/05/1894 & $\begin{array}{l}\text { uncer- } \\
\text { tain }\end{array}$ & 18.5 \\
\hline NHMV & 270 & Sylvia crassirostris & Split & & & 19 \\
\hline
\end{tabular}

